\title{
The benefit of using plastic-covered mattresses and pillows on the frequency of asthma attacks in children with house dust mite allergy
}

\author{
Luh Putu Winansari Ratih, MD; Hendra Santosa, MD
}

\begin{abstract}
Background House dust mite (HDM) is abundant in tropical areas with an environmental temperature of $25-30^{\circ} \mathrm{C}$ and humidity of more than $50 \%$. Minimizing exposure to HDM allergens will decrease the frequency of asthma attacks in children with HDM hyperreactivity.

Objective To investigate the benefit of using plastic covered mattresses and pillows in decreasing the frequency of asthma attacks in children allergic to HDM.

Methods This is a longitudinal analytical study on children aged 3-12 years who showed positive HDM skin prick test (SPT). The subjects received communication, information, and education (CIE) for the first 3 months and $\mathrm{CIE}$ and plastic-covered mattresses and pillows for the second 3 months. The frequency of asthma attacks was observed for the two periods.

Results Twenty-six children with asthma were included in this study, 16 were boys and 10 were girls. SPT results were +2 in 17 children, +3 in 8 children, and +4 in 1 child, respectively. During the $\mathrm{CIE}$ as well as the CIE + plastic intervention periods, asthma attack frequency was decreased significantly in the $1^{\text {st }}, 2^{\text {nd }}$, and $3^{\text {rd }}$ months. Among several variables (age, sex, SPT, atopic history in first-degree relative, and other atopic history), age was the only one significantly related to asthma attack frequency.

Conclusion Covering mattresses and pillows with plastic decreased the frequency of asthma attacks in children with positive SPT to HDM [Paediatr Indones 2005;45:60-64].
\end{abstract}

Keywords: asthma attack, house dust mite, prick test, CIE, plastic covered mattress, pillow
I n 1998, WHO estimated 100 -150 million people had asthma, with world mortality rate reached 180,000 people. Asthma is found in about $10-20 \%$ of children, $75 \%$ of them will continue to have asthma until adulthood. ${ }^{1}$

Asthma attacks can be caused by infection or atopy. Infection in asthma was commonly due to respiratory syncytial virus and parainfluenza virus while atopy can be caused by indoor or outdoor allergen. Outdoor allergen are tree pollen, grass pollen, ragweed and mold spore which is usually found in the subtropical countries, while indoor allergens are household pets and house dust mite (HDM) which occurs in the tropical - subtropical climates.

$\mathrm{HDM}$ is one of the indoor allergen that triggers $85 \%$ asthma attacks in children. HDM allergy is often seen in the tropical countries where the air temperature is about $30^{\circ} \mathrm{C}$ and the relative humidity is above $50 \% .^{2}$ Franky, in his study on children with asthma at Sanglah Hospital, found that approximately From the Department of Child Health, Medical School, Udayana
University, Sanglah Hospital, Denpasar, Indonesia.

Reprint requests to: Luh Putu Winansari Ratih, MD, Department of Child Health, Medical School, Udayana University, Sanglah Hospital, Jalan Nias, Denpasar, Indonesia. Tel. 62-361-227911 ext. 128; Fax. 62361-244038; E-mail: ika_unud@yahoo.com. 
$86 \%$ were exposed by $\mathrm{HDM}^{3}{ }^{3}$ while Adhianto in 2001 reported that $42 \%$ of allergic rhinitis in children were caused by HDM. ${ }^{4}$

HDM are difficult to eliminate with vacuum cleaner, since their claws have the ability to tightly grasp on natural or synthetic fiber. Many experts have tried to decrease the amount of this allergen by using vacuum cleaners to clean carpets, acryl benzoate or boiled water to wash textile, or even by covering mattresses with material impermeable to HDM. ${ }^{5-8}$ Material impermeable to HDM remains unavailable in Indonesia, especially in Denpasar. In this study, we tried to investigate the benefit of plastic as a substitute material to cover mattresses and pillows on the frequency of asthma attacks in children with HDM allergy.

\section{Methods}

This study was designed as a prospective study in a single-group open trial on children with asthma caused by HDM allergy proven by skin prick test (SPT). The study was held in the Allergy Clinic of Sanglah Hospital, Denpasar from September 2002 to February 2004. This study was approved by the Ethics Committee of Udayana University/ Sanglah Hospital.

Subjects included in the study were children aged between 3-12 years with a $+2-+4$ SPT for Dermatophagoides pteronyssimus (1:50 dilution produced by Dr. Soetomo Hospital, Surabaya) who lived in the Badung or Denpasar region. Children were excluded if they had non-allergic asthma (due to viral infection), allergic asthma due to cockroaches or cat and/or dog fur (tested using allergen extracts from Hollister-Stier, USA), or refused to be involved in this study. We defined asthma exacerbations as asthma attacks or worsening of asthmatic symptoms and lung function. The frequency of asthma attacks were divided into three groups based on the classification of asthma severity by the National Childhood Asthma Consensus (Konsensus Nasional Asma Anak, KNAA). ${ }^{9}$

Communication, information, and education (CIE) were given at the beginning of study and every month during home visits. Through their parents, subjects were instructed to decrease exposure to aeroallergens by cleaning floors and furniture with wet towels every day, as well as by avoiding dolls, toys, and furniture made from wool as much as possible. They were also asked to wash the dolls and household tools made from wool/textile every week with warm water and to clean and wash mattress covers every week using boiled water. Avoiding humidity in rooms by providing adequate ventilation (enabling air and sunlight to enter the room) and keeping smoke away from rooms was also encouraged.

Sample size was calculated using an analysis of group proportion probability, in which CIE had 85\% probability and CIE + with plastic covers had $55 \%$ $(\alpha=0.05$ and power $=80 \%$ ). The sample size needed was determined to be 26 subjects.

Subjects were recruited in a consecutive manner. Age, sex, SPT level, atopic history in first-degree relatives, and asthma attack frequency were recorded. Eligible subjects were given CIE once a month for the first 3 months during home visits, and were observed for the frequency of asthma attacks. This was considered as the CIE intervention period. For the three subsequent months, the same group was provided with CIE and their mattresses and pillows were covered with plastic. The frequency of asthma attack was observed, as well as compliance to plastic use. This was considered as the CIE + plastic intervention period.

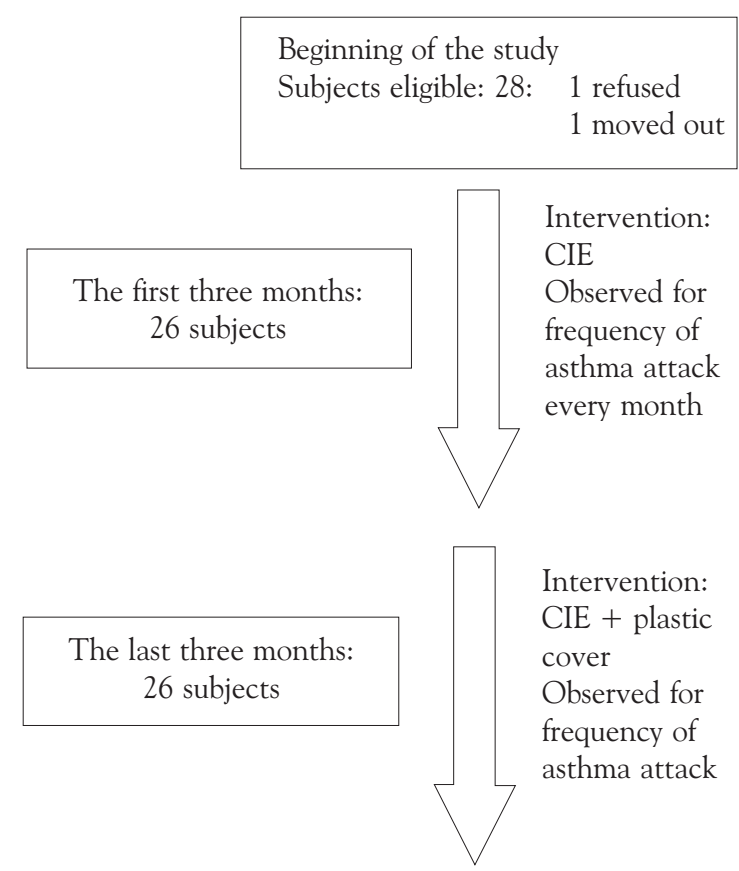

End of the study (overall 6 months): 26 subjects

Figure 1. Diagram of the Study 
A diagram illustrating the chronology of the study is shown in Figure 1.

Data were analyzed using SPSS 11.0. To analyze the pairs of ordinal data with small samples, we used nonparametric tests i.e., the Wilcoxon rank sum test and intervariable association performed with ANCOVA. Statistical significance was set at $\mathrm{P}<0.05$.

\section{Results}

During the study, 28 children 3-12 years of age met inclusion criteria. One subject refused to follow the study and another moved away from the region. Out of 26 children, 16 were boys; 17 had an SPT result of $+2,8 \mathrm{had}$ an SPT of +3 , and $1 \mathrm{had}$ an SPT of +4 . All children had a family atopic history and $23 \mathrm{had}$ atopic history other than asthma (Table 1 ).

Table 1. Characteristics of the study subjects

\begin{tabular}{ll}
\hline Number $(\mathbf{n}=\mathbf{2 6})$ & \\
\hline Age: $3-12$ years old & \\
Boys & 16 \\
Atopic history in first degree relative & 26 \\
Atopic history other than asthma & 23 \\
SPT +2 & 17 \\
SPT +3 & 8 \\
SPT +4 & 1 \\
Subjects compliance & \\
First 3 months (CIE) & 24 \\
Last 3 months (CIE + Plastic) & 25 \\
\hline
\end{tabular}

At the end of the CIE intervention period, the subjects had lower frequency of asthma attacks although they remained in frequent asthma category. However, the reduction of frequency was statistically significant. At the end of the CIE + plastic intervention period, the subjects' asthma attack frequency was significantly reduced to less than one attack per month (Table 2).

To confirm the effect of CIE + plastic interventions, intervariable association analysis was performed with adjustment for age, sex, SPT level, atopic history in first degree relative, and atopic history other than asthma, which resulted in age as the only variable that significantly related to asthma attacks while using plastic covers (Table 3 ).

\section{Discussion}

In this study, we found that more boys than girls had asthma (16/26 versus $10 / 26)$. This result was similar to findings by Franky ${ }^{3}$ and Sheikh ${ }^{5}$. The presence of atopic history in first-degree relatives in many subjects was consistent with the hypothesis that asthma is a genetic disease linked to the short arm of chromosome $5 \mathrm{q}^{3,10}$ This was also genetically related with total $\operatorname{IgE}$ as a marker, as shown in Martinez's study, ${ }^{11}$ in which children with asthma and atopic family history had a total IgE three times higher than that of non-asthmatic children. On the other hand, sensitization to aeroallergens depends on the biology of the allergen, exposure intensity, and the accurate time of exposure.

Data shows that combined CIE and plastic-covered mattresses and pillows intervention would significantly decrease the HDM population in the environment. Arlian ${ }^{12}$ stated that washing mattress covers with boiled water every week would eliminate HDM and its allergens. However, we could not objectively measure the decrease of HDM population while using plastic, since we were unable to collect dust on subjects' mattresses before and after intervention.

Table 2. Frequency of Asthma ATtACKS DURing CIE AND CIE+ PLASTIC INTERVENTION PERIODS

\begin{tabular}{lcccc}
\hline $\begin{array}{l}\text { Asthma } \\
\text { attacks }\end{array}$ & $\begin{array}{c}\mathrm{CIE} \\
(\mathrm{n}=26) \\
\text { median } \\
\text { (interquartile) }\end{array}$ & $\begin{array}{c}\mathrm{CIE}+\text { Plastic } \\
(\mathrm{n}=26) \\
\text { median } \\
\text { (interquartile) }\end{array}$ & $\mathrm{Z}^{*}$ & $\mathrm{P}$ \\
\hline $1^{\text {st }}$ month & $3(3-3)$ & $1(1-2)$ & -4.434 & 0.000 \\
$2^{\text {nd }}$ month & $3(2-3)$ & $1(1-2)$ & -4.401 & 0.000 \\
$3^{\text {th }}$ month & $3(2-3)$ & $1(1-2)$ & -4.137 & 0.000 \\
\hline
\end{tabular}

* $Z$ : $Z$ score; 3 : frequent attacks; 2 : attacks $>1$ / month; 1 : attacks $<1 /$ month

Table 3. Intervariable association duRing CIE and CIE + PLASTIC INTERVENTIONS PERFORMED WITH ANCOVA

\begin{tabular}{lll}
\hline Variable & $\mathbf{F}^{*}$ & $\mathbf{P}$ \\
\hline Age & 4.08 & 0.04 \\
Sex & 0.00 & 0.96 \\
Atopic history in first degree relative & 0.31 & 0.59 \\
Atopic history other than asthma & 0.32 & 0.59 \\
SPT level & 0.31 & 0.59 \\
\hline
\end{tabular}

${ }^{*} \mathrm{~F}$ : ANCOVA 
In this study we hope to demonstrate that the impermeable material would be able to reduce the frequency of asthma by preventing contact between HDM and its products with the subjects. This study also showed that CIE was effective in reducing the frequency of asthma attacks, although the subject remained to have frequent asthma. On the other hand, $\mathrm{CIE}+$ plastic intervention was able to reduce the frequency of attacks significantly from frequent asthma to less than once a month. This is similar to Rijssennbeek-Nouwens' ${ }^{13}$ finding, in which the allergen concentration decreased after four months of treatment. Shapiro also found that impermeable materials were able to decrease HDM population effectively and improve bronchial provocation test result compared to standard intervention control, although the clinical score was not improved.?

CIE has its limitations, as shown by Gotzche's study, in which the subjects were also encouraged to use chemical agents or physical materials for two weeks until one year. This decreased the concentration of HDM, and although symptoms still occurred, the remaining had yet to cause bronchial response in sensitive patients. ${ }^{14}$

Chew in his study showed the benefit of plastic cover as an impermeable material. He found that the risk of asthma attacks from HDM at $10 \mathrm{ug} / \mathrm{g}$ of dust on plastic covers was two times lower compared to the same concentration of HDM on textile covers. ${ }^{15}$ This fact has made plastic more preferable than wool as a mattress cover in America. In line with Chew's finding, Arlian showed plastic to be superior mattress and pillow covers in comparison to other semi-permeable material. ${ }^{12} \mathrm{He}$ also suggested using semi-permeable materials with 10 um size pores to keep away HDM or its products.

In our study, subjects' compliance was found to be high throughout both intervention periods. Complaints on plastic-covered mattress usage was noted in the last three months; subjects complained that the mattress was slippery $(12 / 26)$, made noise during sleep (11/26), and felt hot (3/26).

Using statistical analysis, we found that sex, skin prick test result, atopic history in the family, and atopic history other than asthma did not influence asthma attack frequency, while age did. This also showed that, besides environmental factors, age also played a role on asthma attack frequency. However, in this study, we were unable to measure the age period which influenced asthma attacks frequency. Sensitization to allergens was estimated to come about gradually since early life, initializing with food to viral infection stimulation and continuing with aeroallergen stimulation. Sensitization by aeroallergens does not occur before two years of age, and house dust allergy occurrs earlier than pollen allergy. ${ }^{10}$ Koopman's ${ }^{16}$ study on allergic pregnant mothers who delivered using impermeable materials found that night cough attacks was reduced two years later in comparison with control group.

Our study had some limitations, since the assessment was only based on asthma attack frequency instead of clinical asthma score; data was only obtained by using a monthly questionnaire; HDM population on subject's mattress was not measured; and only a single sample group was studied.

In conclusion, covering mattresses and pillows with plastic may decrease asthma attack frequency in children. Age also influences asthma attack frequency. Children with HDM allergic asthma are suggested to use plastic as mattress and pillow covers as well as to keep the indoor environment clean in order to decrease asthma attack frequency.

\section{Acknowledgments}

The authors are grateful for the advice and thoughtful comments of dr. Raka Widiana, SpPD; Prof. dr. Sudaryat Suraatmaja, SpA(K); Prof. dr. Soetjiningsih, $\operatorname{SpA}(\mathrm{K})$, IBCLC; dr. Komang Kari, SpA; dr. K Dewi Kumarawati, SpA; dr. IB Subanada, SpA; and to all of the families who took part in the study.

\section{References}

1. Santoso P. Perjalanan alamiah penyakit alergi. Presented at The 3rd round table discussion on allergy and immunology: Asma Bronkial, 2001 Oct 27; Denpasar, Indonesia.

2. The mighty dust mite. Available from: http// www.healthquest-nf.com/hqdustmitesinfo.htm.

3. Franky. Peran Dermatophagoides Pteronyssimus terhadap kejadian asma bronkial pada anak di Denpasar. Thesis. Denpasar: bagian Ilmu Kesehatan Anak FK UNUD, 1996. 
4. Adhianto G. Characteristic \& clinical manifestation of allergic rhinitis. Research report. Denpasar: Bagian Ilmu Kesehatan Anak FK UNUD; 2001.

5. Sheikh A, Hurwitz B, Sibbald B, Barnes G, Howe M, Durham S. House dust mite barrier bedding for childhood asthma; randomized placebo controlled trial in primary care. BMC Family Practice 2002;3:12-7.

6. Halken S, Host A, Niklassen U, Hansen LG, Nielsen F, Pedersen S, et al. Effect of mattress and pillow encasings on children with asthma and house dust mite allergy. J Allergy Clin Immunol 2003; 111:169-76.

7. Shapiro GG, Wighton TG, Chinn T, Zuckerman J, Eliassen AH, Picciano JF, et al. House dust mite avoidance for children with asthma in homes of low income families. J Allergy Clin Immunol 1999; 103:1069-74.

8. Vanlaar CH, Peat JK, Marks GB, Rimmer J, Tovey ER. Domestic control of house dust mite allergen in children's bed. J Allergy Clin Immunol 2000;105:1130-3.

9. UKK Pulmonologi, PP Ikatan Dokter Anak Indonesia. Konsensus Nasional Asma Anak. Jakarta: 2000.

10. Akib AAP. Perjalanan alamiah penyakit alergi dan upaya pencegahannya. In: Akib AAP, Tumbelaka AR, Matondang CS, editors. Pendekatan imunolgis berbagai penyakit alergi dan infeksi. Proceedings of
Pendidikan Kedokteran Berkelanjutan Ilmu Kesehatan Anak FKUI XLIV. 2001 Jul 30-31; Jakarta, Indonesia. Jakarta: Balai Penerbit FKUI; 2001.

11. Martinez FD. Complexities of the genetics of asthma. Am J Respir Crit Care Med 1997;156(Suppl):S117-22

12. Arlian LG, Platts-Mills TAE. The biology of dust mites and the remediation of mite allergens in allergic disease. J Allergy Clin Immunol 2001;107 (Suppl):S406-13.

13. Rijssenbeek-Nouwens LHM, Oosting AJ, De bruinWelter MS, Bregmen I, De Monchy JGR, Postma DS. Clinical evaluation of effect of anti allergic mattress covers in subjects with moderate to severe asthma and house dust mite allergy: a randomized double blind placebo controlled study. Thorax 2002;57:784-90.

14. Gotzche PG, Hammarquist C, Burr M. House Dust mite control measures in the management of asthma: meta analysis. BMJ 1998;317: 1105-10.

15. Chew GL, Burge HA, Dockery DW, Muilenberg ML, Weiss ST, Gold DR. Limitations of a home characteristics questionnaire as a predictor of indoor allergen levels. Am J Respir Crit Care Med 1998; 157:1536-41.

16. Koopman LP, Van Strien RT, Kerkhof M, Wijga A, Smit HA, De Jogste JC, et al. Placebo controlled trial of house dust mite impermeable mattress cover. Am J Respir Crit Care Med 2002;166:307-13. 